\title{
Cost Effective Metrics through HRA
}

\author{
M. Rajalakshmi \\ Research Scholar, VIT Business School, VIT University, India \\ Dr. S Gomathi
}

Senior Professor, HRM, VIT Business School, VIT University, India

\section{Doi:10.5901/mjss.2015.v6n3p251}

\begin{abstract}
In an organisation, human resource is the most important resource for organisation development. These resources (HR) are directing and controlling the other resource (Machine and material) for production and organisation profitability. Even though the human resource is very much important to an organisation, but still it is not recognising as an asset factor in the financial balance sheet (financial Statement). This is due to because; there is no proper measurement model for the cost and value of human resource in HRA under many organisations. The Human Resource Accounting will help the organisation for the better future development like, acquisition, expansion, diversification of the organisation. This research is mainly a conceptual paper, which deals with the theoretical aspects of Human Resource Accounting, its measurement on HRA in the organisation and it explains about the influence of HRA in organisation decision making.
\end{abstract}

Keywords: Human Resource Accounting, Human Resource, Cost and Value of Human Resource Accounting, Measurement and Valuation of Human Resource and Models of Human Resource Accounting.

\section{Introduction}

Human Resources are defined as: "The people that staff and operate an organization ... as contrasted with the financial and material resources of an organization." (William R. Tracey, in the Human Resources Glossary).

"Human Resource Accounting is the measurement of the cost and value of the people for the organisation."(Eric Flamholtz of University in California, Los Angeles).

According to the American Accounting Association's Committee on Human Resource Accounting (1973), Human Resource Accounting is nothing but "the process of identifying and measuring data related to human resource and communicating this information to interested parties". From this definition, Human resource accounting (HRA) means, the value and the cost occurred by the employees in an organisation, which includes the cost on, recruitment, selection process, hiring process, and training \& development of the employees. Human resource accounting is the process of measurement, which will help the organisation on the decision making situation. There are two methods have been adopted in HRA, one is cost approach and second is value approach. Cost approach method contains two models are, acquisition cost model and replace cost model. Value approach method also contains three models they are, present value of future earnings method, discounted future wage model, competitive bidding model.

Nowadays, employees are considering has the valuable assets, than the physical and intangible assets in the organization. The HRA will help the organisation to frame out a clear cut financial detail to their management and their investor for predicting and analysing the future potential of the organisation. Moreover, the HR Accounting will help the organisation towards the expansion, Merging and diversification plans and also in tapping the market fund. HRA is not only maid for recognising the value of all resources in the organisation; it needs to provide reorganisation to the human resource which will ultimately increase the quality and quantity of the goods and services in the organisation. This research is basically on the theoretical definition of Human Resource Accounting and the measurement models of HRA.

\section{Accounting for Cost and Value of Human Resource:}

Human Resource Accounting provides the relevant information about the human resources cost and value to the interested peoples like, management, financial analysis and the employees in the organisation. The Human Resource Cost Accounting describes the cost occurred on acquire and develop the employee as well as replacement cost occurred 
in the organisation. The cost of human resource occurred in the organisation will be on the following bases of, acquisition cost, training and development cost, welfare cost and Rewards and recognition cost.

1. Acquisition cost mainly concentrated on the cost on recruitment, cost on selection and cost on interview (Campus \& Organisation).

2. Training \& Development cost concentrated on the cost occurred on the Induction Training Program, on the job training, off the job training, Development Program to the new and existing employees in the organisation.

3. Welfare cost is the cost which taken care of the employees in the organisation like, rewards, incentives, promotions and transfers.

Fig 1: Framework-Cost of Human Resource

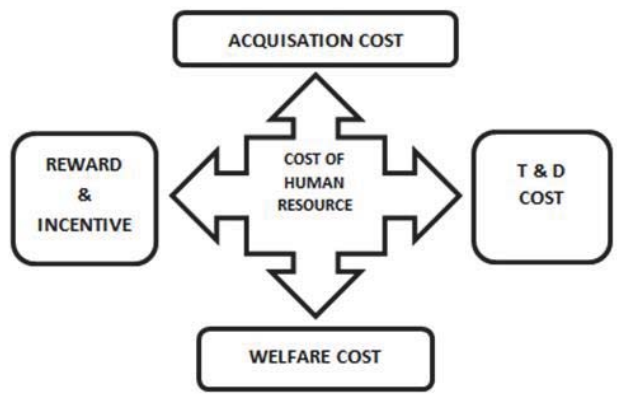

\section{Theories of Human Resource Accounting}

Human Resource Accounting is majorly concentrated on three theories. These theories of HRA focuses on the cost and values of Human Resource in the organisation like, Historical cost, Replacement cost and discounted cash flow. Based on these theories, many organisation start depending there profits from the Intellectual assets (Human Resources) than the Physical assets (Machine). This leads to develop the methods of measuring value of human assets. In India both the private and public sectors have adopted Human Resource Accounting in there organisation. LIKE BHEL, OIL, SAIL, HUL, TELCO, Infosys etc...

Table 1 : Chronological Order of Human Resources Accounting
Introduction in India
\begin{tabular}{|l|l|c|l|}
\hline $\begin{array}{c}\text { S1. } \\
\text { No. }\end{array}$ & $\begin{array}{l}\text { Name of the } \\
\text { Organisation }\end{array}$ & $\begin{array}{c}\text { HRA introduced } \\
\text { in year }\end{array}$ & Model \\
\hline 1 & BHEL & $1973-74$ & Lev and Schwartz Model \\
\hline 2 & ONGC & $1981-82$ & Lev and Schwartz Model \\
\hline 3 & MMTC & $1982-83$ & Lev and Schwartz Model \\
\hline 4 & SAIL & $1983-84$ & $\begin{array}{l}\text { Lev and Schwartz Model with some } \\
\text { refinements as suggested by Eric. G }\end{array}$ \\
\hline 5 & NTPC & $1984-85$ & Lev and Schwartz Model \\
\hline 6 & INFOSYS & $1995-96$ & Lev and Schwartz Model \\
\hline
\end{tabular}

Source: A Report on HRA from http://www.indiamba.com

\subsection{Measurement And Valuation Of Human Resource}

Basically, there are two major approaches to measure and value the human resource in the organisation under HRA. They are,

1. Cost Approach in HRA.

2. Economic Value Approach in HRA.

\subsection{Cost Approach in Hra}

There are two types of cost approaches has been occurs in human resource accounting. They are Historical cost and Replacement Cost. 


\subsection{Historical Cost}

Historical cost is also known as Original cost that occurs in the organisation for the development of Human Resource. Historical cost (or) Original cost is the cost that occurred for the process of recruitment, selection, placement, orientation, and training \& development for the human resource to acquire and develop their skills and ability in the organisation.

\subsection{Replacement Cost}

As the name indicates, the replacement cost is occurred, for the replacement process of an existing employee in the organisation. Due to this replacement cost the organisation should face the historical cost to acquire and develop the new employee in the organisation.

\subsection{Economic Value Approach In Hra}

Economic value based approach will analyse, the future value of the employees merely based on their current performance and service in the organisation. There are two models in the economic value approach. They are, Monetary Measures and Non-Monetary Measures.

\subsection{Monetary Measures}

There are many models given by experts in HRA, to analyse the value of the employees (or) individual in the organisation. The models are Flamholtz's model - determining the Individual Value in the organisation, Flamholtz's stochastic rewards valuation Model and The Lev and Schwartz model. According to Flamholtz's model, (on determining the individual value of the employee) the value of an individual is basically based on the present service that he renders to the organisation. Based on his/her present service their future service will be determined in there organisation. There are two dimensions in this model.

1. Expected conditional value - It means the Productivity, performance, promotions, and transfer to the employee in the organisation.

2. Expected realizable value - Is to know the employee productivity service period in the organisation.

Flamholtz's stochastic rewards valuation model describes the measurement of individual conditional value and the expected realized value of an employee in the organisation. The Lev and Schwartz model According to this model, the value of an individual who is ' $r$ ' year old, is the present value of his future earnings from employment. It can be calculated by using the formula below:

$\mathrm{E}(\mathrm{Vr})=\mathrm{I}(\mathrm{t}) /(1+\mathrm{R}) \mathrm{t}-\mathrm{r}$

Where,

$E(V r)=e x p e c t e d$ value of an 'r' year old individual's human capital

$t=$ the individual's retirement age

$\mathrm{R}=$ discount rate

$\mathrm{I}=$ expected earnings of the individual in period I.

\subsection{Non - Monetary Approach:}

The Non-Monetary measures in human resource accounting describe the economic value of the intellectual assets, but not in the term of monetary. The Non-Monetary measures are,

1. Skills of the human resource in the organisation.

2. Individual performance - Evaluating the individual performance of the human resource and rating there performance level in the organisation.

3. Determine the job satisfaction level of the human resource in the organisation.

\section{Challenges of Human Resource Accounting in HR}

A) The life period of human being is uncertain. Therefore, its value is also uncertain in the organisation.

B) Human Resource is an Intangible asset in the organisation.

C) Implementing HRA in an Organisation will leads high cost. The Human Resource is unable to retain, utilised or 
owned unlike the other tangible assets in the organisation. This makes the management to treat them as asset in the balance sheet.

D) Flamholtz approach is now become a popular model for measuring the contribution value of individual or group in the organisation. Hence, the contribution values of employees are difficult to measure. In Flamholtz approach the career path of the employee (like, promotions, incentives, retirement etc...) should be determined according to their life span in the organisation.

\section{Objectives}

- To expedite effective and efficient management with in an organisation and to know about the work of human resource of an organisation.

- To equip the cost value on effective management decision making about allocating, acquiring, merging and developing the human resource in the organisation.

- To provide the information and measurement about the human resource in an organisation.

- To evaluate the return on investment on human resource capital.

\section{Research Methodology}

Research methodology is a methods used for solving the problem in a systematic way. It is the way to understand the process of research towards the solution on research problem. There is various logical ways for the researcher to adopt the methodology. The research design used in this research is to acquire the information based on the structure and to solve the research problem. A research design is there defined as" A plan, structure and strategy of investigation conceived so as to obtain answers to research question and control variance.

The sample population of this research is taken from the expertise view point on human resource accounting in the organisation. Sampling may be defined as the selection of some part of an aggregate (or) totality on the basis of which a judgment (or) inference about the aggregate (or) totality is made. Random sampling methods have been used in this research among the expertise person on human resource accounting.

Majorly, this research has been concentrated on the cost effective metrics on human resource accounting through the secondary data via. Available books, journals, articles, magazines, newspaper and also relevant websites.

\section{Limitatons of the Study}

Every research has certain specific limitation. The following are some of the limitations of this study.

- Although this research has been done among the expertise person on human resource accounting, this study does not have influence on primary data's. All the information's are gathered from the present employees but not from the past employees.

- The study being corporate sector and the company information cannot be generalized.

\section{Historical Written Leaflets}

Bhavin M Badiyani (2012) this article explains about the history of human resource accounting based on the value of human resource in the organisation. This study describes about the various concepts that occurs in HRA and also deals with various models like, Flamholts model - determinants of individual value, Flamholtz's model of stochastic rewards valuation, and the Lev and schwartz model under human resource accounting in the organisation. Various organisations will adopt various HRA models depends upon their economic growth or the management. This article describes the value of human resource in human resource accounting in the balance sheet of the organisation.

Raunak Narayan (2010) explains the empirical data's analysis regarding the human resource accounting in the organisation. this article briefly deals on the evaluation of human resource according to their performance, skills, motivation and contribution to the organisation and as well as it also concentrate on the organisational process like, recruitment, selection, training etc... The main objective of this study is to know the practise of human resource accounting in the organisation. This article is also deals with the various models, approaches, issues and challenges that occur in HRA practises. In this, the value of human resource is also measured in the terms of monetary approach.

Neha Seth (2009) this study is a conceptual review. It explains about the measurement of cost and value of the 
employee in the organisation for the purpose of Human resource Accounting. In this study, they have discussed on concepts, various models, valuation, and measurement of human resource in HRA especially in Indian Enterprises. The aim of this article is that the organisation should denote the cost and value of human resource in the balance sheet. This article includes Lev and Schwartz model to calculate the human values and it also provide suggestion and improvements in the field of HRA.

Leyira Christian Micah, Clifford O. Ofurum, and John U. Ihendinihu (2012) have done an empirical study on firm's financial performance and human resource accounting in Nigeria. This study deals with the statistical data on the effects of firm's financial performance and the variation of HRA in the organisation. This article explains about the measurement and importance of HRA in the organisation among the investors, stakeholders, and interested people. Simple random sampling technique has been used in this survey. As well as other statistical techniques like, descriptive, correlation, and regression is also used in this survey for analysing data.

Naveed Iqbal Chaudhry (2010) this paper examines the exploratory study on Accounting for the development of human capital in manufacturing organizations under textile industry in Pakistan. In this study convenience sampling has been used for data collection and the sample size as been taken from 30 different textile industries in Pakistan. It majorly describes how investment should be made on development of human resource and to measure the financial return of the organisation. It also focuses on the employee training and development to increase the organisation development.

Dr. Munivenkatappa, Jagadeesh S.R, and Bharathi. K.V (2013) this study focuses on the Human Resource Accounting system in it and manufacturing sector. It is an empirical study paper and percentage analysis is used for data collection. This study explains about the performance and profitability of human resource and considering it on Human Resource Accounting. This research is mainly concentrated on it and manufacturing sectors. It leads on the concept of $\mathrm{HR}$, replacement cost, and the economic value of people in the organisation.

Jacob Cherian \& Sherine Farouq (2013) explains the review of human resource accounting and organisation performance. It also deals with the theoretical aspects of HRA and implementation of HRA models in the organisation. The main objective is to know about the HR practises in the firm. This article describes about the HR practises, challenges in HRA implementation, measuring the employee performance in the organisation. This study includes the adaption process of HRA technology and can be extended to evaluate the different types of intellectual property.

Khaled Jamal Jaarat (2013) explains an empirical study on the Recognition and Measurement of human resource accounting in the organisation. This research paper adopts qualitative and descriptive study for data analysis. This study mainly concentrated on the recognition, measurements, intangible assets, and employee benefits in the organisation.

The sample size is 390 for this analysis. In this study they describe the recognition and measurement of employee values in Human Resource Accounting.

Fig.2: Theoretical Framework - Cost And Value Of Human Resource Accounting In Hr

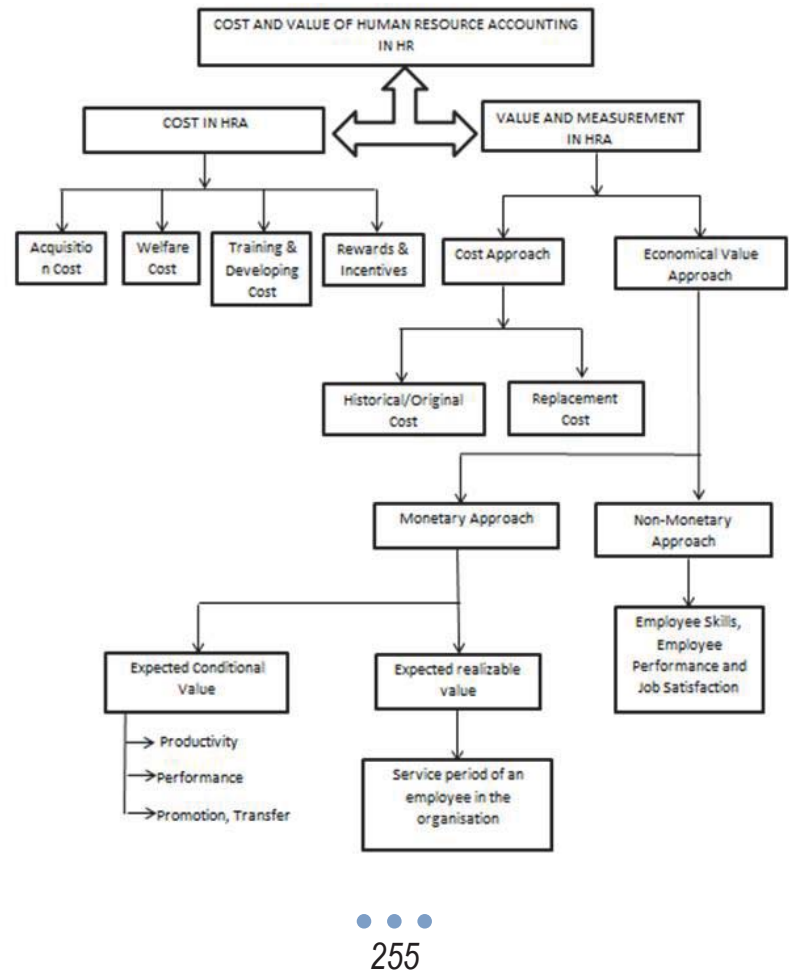




\section{Conclusion}

The employees are the greatest assets of an organisation. The success and failure of the organisation is merely depends upon the performance and service quality of an employee. But this valuable human asset (or) intellectual asset was missed in the traditional accounting method. This HRA will help the organisation to monitor the use of human resource and increase the awareness on human value in the organisation. And it also enables the long-time prospect for planning and budgeting. The HRA implementation helps to improve managerial decisions like layoffs, better performance evaluation measures of the firm and also acts as a guide during buying, selling and merger transactions in the organisation.

\section{Referneces}

Bhavin M. Badiyani (2012), Human Resource Accounting: Brief History and Popular Models, Quest International Multidisciplinary Research Journal, Volume - I, Issue - II.

Bullen, M.L. et al: (2010), "Human Resource Accounting and International Developments: Implications for Measurement of Human Capital", Journal of International Business \& Cultural Studies, Vol. 3 No. 3, Pp. 1-16.

Elias et al: (1986), Behavioral Impact of Human Resource Accounting, Management Accounting (Pre-1986); Feb 1976; 57, 8; ABI/INFORM Complete Pg. 43.

Flamholtz et al: (2002), Human Resource Accounting: A Historical Perspective and Future Implications, Management Decision; 2002; 40, 10; ABI/INFORM Complete (Emerald Group Publication) Pg. 947.

Jacob Cherian1 et al: (2013), A Review of Human Resource Accounting and Organizational Performance, International Journal of Economics and Finance; Vol. 5, No. 8.

Khaled Jamal Jaarat (2013), Human Resources Accounting Between Recognition and Measurement: An Empirical Study, Journal of Business Studies Quarterly, Volume 5, Number 2.

Leyira Christian Micah et al: (2012), Firms Financial Performance and Human Resource Accounting, Disclosure In Nigeria International Journal Of Business And Management; Vol. 7, No. 14, Published By Canadian Center Of Science And Education.

Munivenkatappa et al: (2013), Human Resources Accounting System in It and Manufacturing Sector-A Study, IJMT International Journal Of Marketing And Technology, Volume 3, Issue 12.

Naveed Iqbal Chaudhry et al: (2010), Accounting For The Development Of Human Capital In Manufacturing Organizations A Study Of The Pakistani Textile Sector Journal Of Human Resource Costing \& Accounting, Vol. 14 No. 3, 2010, Pp. 178-195, Emerald Group Publishing Limited.

Neha Seth (2009), Human Resource Accounting Practices, Adopted In Indian Industries ASBM Journal 104 of Management, II (2).

Raunak Narayan (2010), Human Resource Accounting: A New Paradigm in the Era of Globalization, Asian Journal of Management Research.

Savich et al: (1986), Cost/Benefit Analysis of Human Resource Accounting Alternatives, Human Resource Management (Pre-1986) Pg7.

\section{Web Link}

Http://Arividam.Wordpress.Com/2012/06/14/Hra/

Http://En.Wikipedia.Org/Wiki/Human_Resource_Accounting 